\title{
Phraseological units in American and Russian governmental blogs
}

\author{
Rimma N. Salieva - Natalia V. Konopleva - Lilia M. Mirgalimova
}

\section{DOI: 10.18355/XL.2016.09.04.58-67}

\begin{abstract}
The article is devoted to transformed phraseological units studies implied in mass media, particularly, in blogs. Using materials of American and Russian governmental blogs we studied modified variants of phraseologisms, described mechanisms of transformations and made up a classification of transformations. Special attention is given to deviations of semantical stability within the structure of phraseological units and to transformations which appear when such deviations occur.
\end{abstract}

Key words: phraseological unit, semantic stability, phraseological transformation, modification of a phraseologism, blog

\section{Introduction}

The aim of our research is to define the criteria for phraseological transformation, to investigate the nature, to describe significative and denotative meaning of transformed units, to describe evaluative, emotional expressive and functional stylistic components of connotations, to elicit transformational paradigm systems and to illuminate cases of contextual transformation of phraseological units.

The definition of a phraseologism, its peculiarities and its nature are discussed by both: classic old school of linguistics and young scientists. Established colocations are reproducible syntagms, i.e. word phrases, phrases, predicative phrases and stable sentences with peculiar semantics, which are further subdivided into: 1) phraseological unities ("Phraseologische Einheiten": den Mund halten; die Beine unter die Arme nehmen); 2) stable sentences ("Festgeprägte Sätze": Da liegt der Hund begraben; Wer den Wein trinkt, muss auch die Hefe trinken) - phraseologisms having syntactic structure of a sentence (proverbs and sayings); 3) collocations ("Phraseologische Verbindungen": kalte Miete; warme Miete; blinder Passagier); 4) lexical unities ("Lexikalische Einheiten": der Nahe Osten und Nahost; die kontrastive Grammatik) (Stepanova, 2003: 176, 181, 192, 197, 219). T.N. Fedulenkova considers a phraseologism as a linguistic unit defined in dictionary with the help of signs of secondary naming, which is characterized by bipartite dichotomy of content and meaning: a) the content of a phraseological unit - its meaning; b) the content of a genetic model of a phraseologism - the meaning of a genetic model of a phraseological unit. The content of a genetic model of a phraseologism consists of materialistic - phonic or graphical substance - components, its meaning is composed of word meanings its components (Fedulenkova, 2000:132). According to V.I. Maksimov, "phraseological unit is a word or a sentence having tightly bound components and used in certain syntactic roles (like word combinations and sentences) as a ready-made elements of speech" (Maksimov, 2004: 230). This definition underlines the fact that phraseological units are ready-made but not created in a process of speech or writing as new combinations.

In our work we stick to the definition of A.V. Kunin: "Phraseological unit is a stable combination of lexical items with fully or partially metaphorical figurative meaning", however, as the scientist claims there is no common viewpoint on a criterion of "stability" of phraseological units and the most common understanding of it is "being ready-made and used unchangeably" (Kunin, 1972: 5). 
All the definitions we considered have some criteria of phraseologisms in common and these are stability and repeatability.

A.V. Cunin has a complex approach to the problem of stability. He defines it as amalgamation of stability of usage, semantic stability, structural semantic stability, lexical stability and syntactical stability. In this work we consider only semantic stability, which responsible for "stability of figurativeness of meaning, the existence of synonymous meaning and lexical invariant, phraseological variations and semantic invariants" (Kunin, 1972: 5-7).

Our research investigates semantic transformations paying special attention to the notion of semantic stability as transformation presupposes modifications not only in semantic but also structural, grammatical and other components of the existing phraseological units. Any transformation is a purposeful modification of a phraseological unit. Customarily modifications are marked stylistically as a result of full or partial change in the meaning of a phraseological unit, these changes freshen up or renew the meaning. Such refreshments are implied not only in literary works, but also in political discourse, which is oriented for a common reader. We investigate phraseological modifications on a semantic level in the context of governmental blogs of Russia and the USA. Reconsideration as a change in meaning can be illustrated with the help of the following example:

"In later years, as I became interested in photojournalism, it was the photographs that brought that awful day to life form",

in which the phraseological unit to bring to life is used in the speech of one of the photographers of the White House not in the meaning 'to bring to senses', which is found in the Dictionary of Idioms in the section devoted to medical terms, but in this case it describes human feelings which are being personified. Photos are seen as tools of going deep into history and the photographer experiences these terrifying events.

Phraseological unit "последняя миля" with the meaning "relative distance between ATS and its dial-up user' in Russian language (Spravochnik technicheskogo perevodchika,2015) is widely used in negotiations and articles devoted to the theme of electrical energy industry. This phraseological unit became a term after the energetic reform in 2006 and now can be used both as a term and as a phraseologism like used in the speech of D.A. Medvedev given in the following sentences:

"Разработка Минэнерго и ФСТ нового варианта решения проблемь последней мили в электроэнергетике”. Authors' translation: "RF Ministry of Energy and FTS elaborates a new way of solving electroenergetic last mile problem".

"Компромиссное решение Минэнерго по последней миле: крупные потребители продолжат платить распределительным компаниям”. Authors' translation: "Compromise solution of RF Ministry of Energy for the problem of the last mile is that large consumers continue paying distributing companies".

N.G. Bragina studies remembering these or those word combinations and their repetition in oral or written speech. She believes that stability is a motivated linguistic category, and different discourse types like mythological, literary, philosophical, political and many others are its motivational background... Phraseological units make up collective cultural memory field (Bragina, 1999: 134)". In this work we analyse phraseological "behavior" in political discourse. For instance, a phraseological unit to give smb. a leg-up with the meaning 'to help somebody to win up a horse or to climb up on something' (McGraw-Hill "Dictionary of American Idioms and Phrasal Verbs, 2015) is reconsidered in the economical context and gets the meaning different from the initial one and the new meaning is 'offering financial accommodation'. The phraseological unit gets such meaning in the following context in the speech of B. Obama devoted to business development: 
"Take a look at Marilu's and Kendra's stories to see exactly what happens when you give hardworking Americans the leg up they deserve".

"Working Americans who are out there struggling every day, doing the right thing, supporting their families and trying to get a leg up in this new economy".

In the second example the verb give is replaced by get and so the meaning is changed to 'get financial help'.

A bit different usage of this PU is found in the same speech. The derived meaning in this context is 'a start-up help':

"...any American worker looking to invest time and money in training can go online and see which programs have the best chance at giving them a leg up...".

Let us study the usage of colloquial PU in Russian говорить через губу with the meaning 'to speak to somebody unwillingly, with contempt' (Efremova, 2000). PU maintains its meaning 'to speak to somebody with contempt', but the context of the official speech changes the style of the utterance:

"Значит, ни один человек - ни тот, кто учится в университете, ни министр - не должен относиться к новым знаниям пренебрежительно, разговаривать с людьми, которые что-то рассказывают, через губу, типа: да я всё это знаю, что вы нам рассказываете, я вот этими процессами в масштабах огромной России руковожу, а вы мне тут что-то такое предлагаете". Authors' translation: "It means that no one - neither a student nor a minister - can meet new knowledge with contempt as if he or she knows everything and doesn't need to be taught as he manages these processes on a national scale)" (the example is taken from the interview of D.A. Medvedev).

\section{Methodological Part}

To reach our aims in comparative study of phraseological units on linguistic and functional-stylistic level in American and Russian governmental blogs following methods were implied:

- continuous sampling method (samples are taken from governmental blogs of America: (https://www.whitehouse.gov/blog) and Russia (http://government.ru/news/);

- comparative analysis method (the investigated phraseological phenomena met in English and Russian are compared in two unrelated languages);

- definitional analysis method (theoretical ground for this research are works on general linguistics and lexicology by A.N. Baranov, D.O. Dobrovol'skij, V.V. Vinogradov, F. de Saussure and works on phraseology by A.V. Kunin, V.N. Telija, V.I. Maksimov, E.F. Arsentjeva, A.F. Artjomova, R.A. Ayupova, L.K. Bairamova, R.N. Salieva, G.R. Safiullina, Ye.Yu.Semushina, M.D. Stepanova and I.I. Cernyshova.

\section{Results}

\subsection{Results. Transformed phraseological units in usage}

Transformed variants of phraseological units are studied in works of following linguists Ye.F. Arsentjeva (2009), A.F.Artjomova (2009), R.A. Ayupova (2012), A.N. Baranov and D.O.Dobrovol'skij (2006), A.S. Gadakchyan (2013), A.V. Kunin (1972), A.M. Melerovich and V.M.Mokienko (1999), L.K. Bairamova (2013), R.N. Salieva (2009, 2013), R.A. Safina (2013), Ye.Yu. Semushina (2013) and others.

A.V. Kunin was one of the first Soviet scientists who paid attention to occasional usage of proverbs and sayings alongside the category of stability, 
particularly he studied syntactical deviations "causing the effect of defeated expectation and correspondingly change in meaning" (Kunin, 1972: 244).

In one of the works of Russian linguists A.N. Baranov and D.O. Dobrovol'skij besides the category of stability the category of occasionality is mentioned which is referred to the field of language expression synthesis. The scientists define occasionality as a process and as a result of "implying less common rule while forming linguistic expressions. In such special cases less common rule becomes unique" (Baranov, 2008: 55).

Each phraseological transformation is a part of oral or written speech of a person, who occasionally or intentionally refers to certain modification types to achieve some stylistic purpose. A.N. Baranov and D.O. Dobrovol'skij devote a chapter to discuss the question of authorial usage of idioms. It is useful to mention that idioms are not the only phraseological units exposed to modifications. We agree with the linguists on the point that authorial modifications are stable only in the original context. The scientists gave the name of "authorial idiomacity to specific cases of idiom usage which are peculiar to an author and individualize his or her speech" (Kunin, 1972: 495). The linguists distinguish between following authorial modifications of idioms:

- $\quad$ authorial lexical modifications of idioms;

- $\quad$ authorial grammatical transformations;

- authorial semantic modifacations of idioms;

- authorial statistic universals;

- authorial dearchaisms;

- $\quad$ authorial idioms (Kunin, 1972: 495).

Authorial usage of phraseological units is also discussed in works of A.M. Melerovich and V.M. Mokienko who cover problem of authorial aphorisms, the scientists study occasional praseological units "created on the base of proverbs and phraseologisms of a language, which highlight the national wisdom... and reflect the uniqueness of national view of life: folk concepts and symbols" (Melerovich, 1999: 66).

A.F. Artemova considers the question of authorized phraseological units which represent transformations mentioning that modifications can be observed on the level of content and meaning. Special attention is paid to transformed phraseologisms having ambivalent meaning and thus creating humorous effect which is called pun. Non-metaphorical phraseological units may "freshen" with the help of epithet or homogeneous parts addition (Artemova, 2010: 173).

O.N. Antonova's dissertation is related to transformed proverbs in publicistic discourse studies. The work investigates differen from usual usage of transformed proverbs in newspaper style (Artemova, 2009: 1-27).

A.S. Gadakchyan analyses transformation of phraseological units in modern English means of mass-media communication from linguo-pragmatic connotative aspects. As a conclusion she points out between simple, complex and compound attributive expansion, ellipsis and phraseological allusion (Gadakchyan, 2013: 186 190).

A.M. Melerovich and V.M. Mokienko study phraseological transformations from the viewpoint of individual attitude to evaluative stereotypes which is expressed with the help of metalinguistic commentaries. So in the article «Формирование и функционирование фразеологизмов с культурно маркированной семантикой в системе русской речи(Forming and functioning of Russian culturally marked phraseologisms in speech)» we found ways of transformation which are not subdivided into classification:1) first, it is a literalization of meaning is a "metalinguistic commentary expressing authors attitude to actual meaning and inner 
form of a phraseological unit, individual perception of a phraseologism is introduced like real etymological meaning of a unit, 2) then the scientists mention "usual socialized evaluation of a phraseological unit in a context which is reconsidered via etymology and metalinguistic commentaries and with the help of addition of expressive and evaluative words, and 3) expansion through adding non-expressive components (Melerovich, 1999: 64).

\subsection{Results. Behaviour of phraseological units in mass media}

Appearance of new functional styles in mass media (including language of blogs) is possible due to electronic means of mass communication development. "It determines the specificity of language used in mass media" (Maksimov, 2004: 53).

The language of blogs is a combination of written and oral speech. In this work we give examples taken from briefings, videos, interviews and news columns in the practical part. Many ideas get ideological interpretation and sometimes stereotypization as we can see:

«Working Americans who are out there struggling every day, doing the right thing, supporting their families and trying to get a leg up in this new economy» (B. Obama). This example is taken from the speech devoted to middle class families. Here we observe a description of common American family.

The following example illustrating the presence of political ideology and appeal to readers is taken from D.A. Medvedev's report:

«Люди начинают уважать духовные традиции, культуру других народов, проживающих на территории Республики Крым, хотя раньше власти Украины пытались вбить клин $u$, соответственно, сделать неприемлемым существование на одной территории людей разных национальностей (Реорlе start respecting traditions and culture of other nations living in Russia in spite of the fact that earlier the Ukraine tried to "force a wedge"between nations to make it impossible)».

Blog texts are stylistically close to newspapers language only the way of information delivery is different. As G.Ya. Solganik states linguistic means are chosen to give social evaluation of facts and events (Solganik, 1981: 11). And V.N. Teliya underlines that phraseology is interesting to investigate from cultural point of view. Some references to real peculiarities to American or Russian culture are also found in blogs:

“...Не ставит даже приставной стульчик, а целенаправленно держит ее на правах “бедной Лизы”: свидания, которые никогда не закончатся свадьбой... (Doesn't even invites to a table but intentionally makes "Poor Liza" of it: dates that would never have happy end)". Poor Liza is a heroine of a sentimental novel by N.M. Karamzin.

"Together, we can make sure that every Native young person is treated like a valuable member not only of your nation, but of the American family-- that every Native young person gets an equal shot at the American Dream". American dream is purely American concept and no other national dreams are met among cultures.

Phraseology makes images connected with the mentality of a nation, with religion, rituals, mythology, lifestyle, folklore, world, nature and weather learning styles and stereotypes. V.N. Teliya expresses results of her observation in one of her articles saying that "most phraseological units are culturally marked. National memory saves intertextual connection to certain cultural code or symbol which can be traced in cultural reference of an individual, repetition of phraseological signs leads to forming of individual cultural self-consciousness and national identity: мать сыра земля (mother earth), выносить сор из избы (tell tales out of school), перемывать косточки (chew the fat) (Stepanova, 2003: 14). 
T.V. Akhutina citing "Theses" (1929) of Prague linguistic circle underlines that "the simples goal of any speaker is expression... From that viewpoint language is a system of expressive means serving a certain purpose" (Artemova, 2009: 23). So phraseological transformations in speeches of blog-writers help them reach their aims.

\section{Discussion}

\subsection{Discussion. Transformations in blogs}

It is necessary to note that all transformations represented in our work can become common lexis any time and they are transformations only at a given moment of study. Frequent repetitions in speech may cause such transferences as "any fact of evolution follows a group of language facts or events, in the history of any novelty we meet two moments: 1) creation of a novelty by an individual and 2) the moment of transference of a novelty to linguistic fact, the moment when it is admitted by society" (Sossyur, 1991: 97).

1. After analyzing modifications among phraseological units which were chosen with the help of continuous sampling method from the White House blog we distinguished between following types of transformations:

- deviation from lexical stability is represented by component replacement, attributive expansion and ellipsis;

- $\quad$ morphological deviations in the form addition or replacement of
suffixes;
-
deviation from structural-semantic stability; meaning (metaphorical or metonymical) and literalization of meaning of a phraseological unit;

deviation from stability of usage deals with cases of usage of a phraseological unit in context not peculiar to its usage field;

- deviation from structural stability;

- contamination.

2. Having studied transformations of phraseologisms implied in the Governmental blog of Russia we pointed out following cases:

attributive expansion and ellipsis;

deviation from lexical stability: component replacement,

- morphological deviations in form of addition or replacement of affixes and non-standard usage of singular and plural;

- deviation from structural-semantic stability;

- deviation from semantic stability in form of reconsideration of meaning and literalization of meaning of a phraseological unit;

- deviation from the stability of usage represented in usage of a phraseologism in context different from usual;

- deviation from structural stability;

- contamination;

- non-translated usage of foreign phraseological units (so called phraseological barbarisms). 


\subsection{Discussion. Deviation from semantic stability}

Deviation from semantic stability can be observed in cases of meaning reconsideration and literalization of meaning. Reconsideration (or change in meaning) becomes possible when a phraseological unit is used in an indistinctive for it context.

For instance we find a phraseological unit zeros \& ones used as a title for the American president's speech "Zeros \& Ones" with an interpretation 'a group of budding computer scientists' given after, though the expression is usually implied to denote 'a binary code' in Technical Dictionary (http://techterms.com/definition/digital, 2015). In our case it is not a term but an address to a group of scientists-programmers. This example is a case of metonymy as PU is addressed to a group of people naming "objects" they are working with.

Deviation from semantic stability is observed in the following sentence where PU to set eyes on smb./smth. with the meaning 'to see; look at' as given in American English Dictionary (http://www.collinsdictionary.com/dictionary/american/lay-or-setor-clap-eyes-on?showCookiePolicy=true, 2015) has a shift in meaning and is understood as 'to plan or to wish to fulfill or make something come true' in the context:

"So she set her eyes on becoming a cardiac sonographer for Kaiser" (B. Obama, honoring medical workers).

1. A phraseological unit to shine a light on defined in Roget's 21st Century Thesaurus, Third Edition Copyright (c) 2013 by the Philip Lief Group (http://www.thesaurus.com/browse/shine some light on, 2015) as 'to raise the curtain, start a performance' gets a meaning of a cliché to throw light on which is more often used in the meaning 'to explain, make clear' in negotiations devoted to nature care:

"These frank conversations helped to shine a light on the work left to be done, and possible community and government solutions" (B. Obama).

Literalization of meaning is one more type of transformation which breaks a rule of semantic stability. The usage of phraseological unit on the final leg with the meaning 'at the end of the marching column', literally 'with the last leg joined to a parade' can be observed in the following example:

"Thousands of people joined along the way to Montgomery, with roughly 25,000 people entering the capital on the final leg of the march".

This expression is taken from the field of civic aviation and is referred to a landing process (Cowie, 1994: 213, 241).

Metaphorical usage of an expression сверить часы 'to compare notes' in Russian and its derivative сверка часов 'comparing notes' in political context is supposed to be borrowed from English PU to compare notes 'to coordinate positions'. It means "to exchange opinions on some subject, to compare viewpoints" which can be made out of the following situations:

“... у нас есть хорошая возможность не только провести заседание союзного Совмина и поговорить об интеграционных делах, включая Союзное государство, но и просто в очередной раз сверить часы по всей совокупности российско-белорусских отнотений... (Authors' translation: ... we have a good chance not only to held a Council of Ministers meeting but to compare notes with Belorussian colleagues...)" (D.A. Medvedev).

"Понятно, что это довольно короткие встречи, они не сопровождаются подписанием большого количества документов, но это сверка часов, это возможность что-то подтолкнуть... (Authors' translation: "It is obvious that these short-timed meetings do not lead to signing of important documents, they are just coordination of positions and a possibility to improve some things...") (D.A. Medvedev). 
Metaphorical is the usage of a phraseological unit стоять/быть на краю nропасти 'to stand on the brink of a precipice' applied to economic situation of a country in the speech of the Russian president:

"Дальнейшие действия руководства Украины, в том числе военные, привели страну $к$ той экономической пропасти, над которой она стоит ceйчac (Authors' translation: "The actions of the Ukranian government including war actions have brought the country to the brink of a precipice, where it is standing now") (D.A. Medvedev).

The colloquialism oтрубить хвост with the meaning 'to cut off a tail' loses its vulgar tone in the context and polysemantic noun $x 60 \mathrm{~cm}$ saves its colloquial meaning 'the end of something' and as a result we get the meaning 'to shorten queues':

Д.Медведев признал, что "раз и навсегда ликвидировать очередь в детские садь вряд ли получится”. Но поручил “по крайней мере, отрубить xвосm (Authors' translation: "D. Medvedev admitted the necessity of rooting away queues after getting places at kindergartens, at least he requested cutting of its tale").

\section{Conclusion}

The mechanism for lexical transformation is in its inner form. For instance, collocations are exposed to all types of lexical transformations, especially to attributive expansion both in English and Russian. It is possible due to week idiomacity of collocations. As for semantic transformation, imagery of inner form of a phraseologism is a mechanism for transformation which allows speaker or writer play with words. The structure of a proverb or saying presupposes deviations from structural-semantic stability and the structure becomes a model for witty utterances creation. There are also deviations from structural-semantic stability among phraseological units having non-sentencial structure, in such cases the mechanism is also the structure (rhyme or rhythm).

Detailed analysis of deviations on the semantic level let us make few important conclusions. First of all, we subdivided transformations of this type into: 1) reconsideration of meaning, the mechanism to it is an imagery inner form or polisemy of one or several of the components a phraseological unit. Reconsideration of meaning is stylistically marked and is used as expressive means only in a context. Some cases may not follow expressive aims as in examples with terms used in narrowly-specialized areas and now appeared to be in wide usage; 2) literalization of meaning is possible due to policemy of one or several of the components of a phraseological unit, as a result it makes an effect of defeated expectations which is possible only in a context, and out of a context. It is not an expressive means. Such transformations often create ironical or even sarcastic effect.

This work further can be used in lexicological studies, stylistics and methodology.

\section{Bibliograpic references}

ANTONOVA, O. 2012 Funkcional'nye svojstva paremij-transformov v angloyazychnom publicisticheskojm diskurse, p. 27. Moskva: Avtoreferat.

ARSENTYEVA, E. - SAFINA, R. 2015. Expanded metaphor and double actualization of phraseological units in advertising texts. Journal of Language and Literature. Vol. 6, issue 1, pp. 282-286.

ARTEMOVA, A. 2009 Anglijskaya frazeologiya p. 208. Moskva: Vysshaya shkola. ISBN 9785060056198.

AXUTINA, T. 1989. Porozhdenie rechi. Nejroligvisticheskij analiz sintaksisa, p. 215. Moskva: Izdatel'stvo Moskovskogo universiteta. ISBN 5-211-00226-1.

65

XLinguae Journal, Volume 9 Issue 4, October 2016, ISSN 1337-8384 
AYUPOVA R. - ZAMALETDINOV, R. 2014. Types of Phraseological Unit Definition. In E. Arsenteva (ed) Phraseology in Multilingual Society. Cambridge: Cambridge Scholars Publishing, pp. 316 - 328.

BARANOV, A. - DOBROVOL'SKIJ, D. 2008. Aspekty teorii frazeologii, p. 656. Moskva: Znak. ISBN 5-9551-0235-3.

BRAGINA, N. 1999. Fragment lingvokul'turologicheskogo leksikona. In Teliya V.N. Frazeologiya v kontekste kul'tury, p. 336. Moskva: Yazyki russkoj kul'tury. ISBN 588766-061-9.

COWIE, A., MACKIN, R. - MC. CAIG, I. 1994. Oxford Dictionary of English Idioms, p. 686. Oxford: Oxford University Press. ISBN-13: 978-0-19-431287-5. ISBN: 0-19-431287-9.

COWIE, A. 2007. Oxford Dictionary of Current Idiomatic English. Oxford: Oxford University Press.

CRANE, D. - CRANE, D. 1997. Dictionary of aeronautical terms (3rd ed.). Newcastle, Wash.: Aviation Supplies \& Academics. ISBN 1560272872.

DAVLETBAEVA, D. - YARMAKEEV, I. 2014. Lexicographic Presentation of Phraseological Transforms. In E. ARSENTEVA (ed) Phraseology in Multilingual Society. Cambridge: Cambridge Scholars Publishing, pp. 329 - 338.

EFREMOVA, T. 2000. Novyj tolkovo-slovoobrazovatel'nyj slovar' russkogo yazyka, p. 1233. Moskva: Drofa. ISBN 5-200-02800-0.

FEDULENKOVA, T. 2000. Anglijskaya frazeologiya. Lecture presented in PGU, Arxangel'sk.

GADAKCHYAN, A. 2013. Chastotnye modeli transformirovannnyx frazeologicheskix edinic $\mathrm{v}$ yazyke sovremennyx angloyazychnyx SMI: lingvopragmatichsekij i kognitivnyj aspekty.Vestnik Chelyabinskogo gosudarstvennogo universiteta, 73, 190-190. Retrieved August 31, 2015. ISSN 19979886.

KUZ'MIN, S. 2001. Russko-anglijskij frazeologicheskij slovar' perevodchika, p. 776. Moskva: Flinta. ISBN 5-89349-301-X.

KUNIN, A. 1972. Frazeologiya anglijskogo yazyka, p. 288. Moskva: Mezhdunarodnye otnosheniya. ISBN 046894

MAKSIMOV, V. 2004. Stilistika i literaturnoe redaktirovanie p. 651. Moskva: Gardariki. ISBN 5-8297-0149-9.

MELEROVICH, A. - MOKIENKO, V. 1999. Formirovanie funkcionirovanie frazeologizmov s kul'turno markirovannoj semantikoj $\mathrm{v}$ sisteme russkoj rechi. In Teliya V.N. Frazeologiya v kontekste kul'tury, p. 336. Moskva: Yazyki russkoj kul'tury. ISBN 5-88766-061-9.

NACISCIONE, A. 2016. Chapter XII. Extended Metaphor in the Web of Discourse. In W. Raymond and Jr. Gibbs (eds) Mixing Metaphor. Amsterdam / Philadelphia: John Benjamins Publishing Company, pp. 241-266.

SALIEVA, R. 2009. Sopostavitelnyi analiz frazeologicheskikh edinitc s prozrachnoi vnutrennei formoi v angliiskom i russkom iazykakh. Kazan: Kazan. gos. un-t.

SALIEVA, R. - NURULLOVA, A. 2014. Phraseological Units with Onomatopoeic Component and Transparent Inner Form. In E. Arsenteva (ed) Phraseology in Multilingual Society. Cambridge: Cambridge Scholars Publishing, pp. 71-82.

SOSSYUR, F. 1991. Kurs obshhej lingvistiki, p. 296. Moskva: Logos. ISBN 5-81630005-9.

SOLGANIK, G. 1981. Leksika gazety, p. 112. Moskva: Vysshaya shkola. ISBN 57695-0929-5.

STEPANOVA, M. - CHERNYSHEVA, I. 2003. Leksikologiya sovremennogo nemeckogo yazyka, p. 253. Moskva: Akademiya. ISBN 5-7695-0929-5. 
TELIYA, V. 1999. Frazeologiya v kontekste kul'tury. In Pervoocherednye zadachi i metodologicheskie problemy issledovaniya frazeologicheskogo sostava yazyka $\mathrm{v}$ kontekste kul'tury, p. 336. Moskva: Yazyki russkoj kul'tury. ISBN 5-88766-061-9.

(n.d.). RETRIEVED AUGUST 31, 2015, from http://www.fisiologia.ufc.br/ABS/McGraw-

Hill's.Dictionary.of.American.Idioms.and.Phrasal.Verbs.pdf

(n.d.). RETRIEVED AUGUST 31, 2015, from http://www.thesaurus.com/browse/shine some light on

Digital. (n.d.). Retrieved August 31, 2015, from http://techterms.com/definition/digital

LAY EYES ON. (n.d.). Retrieved August 31, 2015, from http://www.collinsdictionary.com/dictionary/american/lay-or-set-or-clap-eyes-

on? showCookiePolicy=true

PORTAL PRAVITEL'STVA ROSSII. (n.d.). Retrieved August 31, 2015, from http://government.ru/news/

THE WHITE HOUSE BLOG. (n.d.). Retrieved August 31, 2015, from https://www.whitehouse.gov/blog

ZHIVOJ ANGLO-RUSSKIJ SLOVAR' PO VYCHISLITEL'NOJ TEXNIKE, INFOMACIONNYM TEXNOLOGIYAM I SVYAZI. (n.d.). Retrieved August 31, 2015 from http://www.morepc.ru/dict/

Words: 4416

Characters: 30529 (16,96 standard pages)

Assoc. Prof. Rimma Nailevna Salieva

Department of Germanic Languages

Institute of Philology and Intercultural Communication

Kazan Federal University

18, Kremlyovskaya St., 420008 Kazan

Republic of Tatarstan, Russia

sargus5@yandex.ru

Assoc. Prof. Natalia Vjacheslavovna Konopleva

Department of Languages \& Intercultural Communication

Institute of Philology and Intercultural Communication

Kazan Federal University

18, Kremlyovskaya St., 420008 Kazan

Republic of Tatarstan, Russia

natali.konopleva@mail.ru

Lilia Marselevna Mirgalimova

Department of Germanic Languages

Institute of Philology and Intercultural Communication

Kazan Federal University

18, Kremlyovskaya St., 420008 Kazan

Republic of Tatarstan, Russia

lilya_mirg1991@mail.ru 